\title{
Physiological Changes in Red Onion Bulbs at Different Storage Temperature
}

\author{
Mouluda Sohany ${ }^{*}$, Md. Kamal Uddin Sarker², Md. Sultan Mahomud1 \\ ${ }^{1}$ Department of Food Engineering and Technology, Hajee Mohammad Danesh Science and Technology \\ University, Dinajpur, Bangladesh \\ ${ }^{2}$ Department of Agricultural and Industrial Engineering, Hajee Mohammad Danesh Science and Technology \\ University, Dinajpur, Bangladesh \\ Email: sohani044@gmail.com
}

Received 11 April 2016; accepted 20 May 2016; published 23 May 2016

Copyright (C) 2016 by authors and Scientific Research Publishing Inc.

This work is licensed under the Creative Commons Attribution International License (CC BY). http://creativecommons.org/licenses/by/4.0/

(c) () Open Access

\begin{abstract}
Onion bulbs were stored at five different temperatures to know the storage behavior of onion bulbs. Indian red onion bulbs were kept without wrapping at ambient conditions $\left(25^{\circ} \mathrm{C} \pm 3^{\circ} \mathrm{C}\right.$ and $\left.75 \% \mathrm{RH}\right)$ and within polyethylene pouch at $2.5^{\circ} \mathrm{C}, 6^{\circ} \mathrm{C}, 7^{\circ} \mathrm{C}$ and $13^{\circ} \mathrm{C}$ for 60 days of storage period. Weight loss, total soluble solids (TSS), number of sprouted and rotten bulbs were measured at an interval of 10 days throughout storage. The greatest decrease $(23.25 \%)$ in weight was observed throughout storage for onions stored at ambient conditions. TSS was observed to increase in all samples until 40 days of storage and then decreased up to 60 days. Lowest TSS $\left(14.89{ }^{\circ} \mathrm{Bx}\right)$ was found in onion stored at ambient conditions at the end of storage. Maximum sprouted $(67.25 \%)$ and rotten $(17.78 \%)$ onions were observed for onions stored at $13^{\circ} \mathrm{C}$, whereas minimum sprouted and rotten onions were found at $2.5^{\circ} \mathrm{C}$ at 60 days of storage. Results also recommend lowest temperatures $\left(2.5^{\circ} \mathrm{C}\right.$ $6^{\circ} \mathrm{C}$ ) for prolong storage life of onion with no detrimental effects.
\end{abstract}

\section{Keywords}

Onion, Onion Bulb, Allium cepa, Physiological, Storage Behavior

\section{Introduction}

Onion (Allium cepa) belonging to the family Alliaceae is mostly consumed bulb crop around the world. Onion is believed to be originated in Asia but cultivated in most of the countries around the world [1]. Although, onion is primarily consumed as spice in various dishes for unique flavor and pungency taste because of volatile oil allyl-

*Corresponding author.

How to cite this paper: Sohany, M., Sarker, M.K.U. and Mahomud, M.S. (2016) Physiological Changes in Red Onion Bulbs at Different Storage Temperature. World Journal of Engineering and Technology, 4, 261-266.

http://dx.doi.org/10.4236/wjet.2016.42025 
propyl-disulphide but it plays significant role in human nutrition with medicinal properties [2]. The onion either as mature bulb or green leaves, is not only popular for culinary purpose, but also rich source of calcium, sodium, phosphorous, fiber with no fat [3] [4].

In Bangladesh, onion ranks first in production among spice crops with the yearly production of 8.89 lakh metric tons in the land of 1.25 lakh hectares [5] but it can't meet the increasing demand of onion. On the other hand, poor postharvest management with improper preservation technique results in 22\% of postharvest loss [6], poor quality and ultimate acute shortage of onion in relation to the requirement. Higher respiration with heat generation enhances re-growth of onion during storage and causes moisture loss from bulb and reduces shelf-life [7]. It has been reported that cultivar, storage regime and temperature have profound effect on sprouting and storage life of onion [8].

Usually, onions are grown in cool-dry season and stored throughout the year. Due to lack of cold storage, onions are stored by farmers with traditional technique in shelters at ambient conditions. This traditional storage system results in increased postharvest loss of onion. Consequently, huge amount of onion especially red onion is being imported from India to meet the crisis of onion throughout the year. According to Gubb and MacTavish [9], moisture loss from onion bulb is greater at room temperature of more than $27^{\circ} \mathrm{C}$. Again, hot and humid storage conditions are susceptible for the growth of black mold (Aspergillusniger) [10] [11], bacterial soft rot (Pseudomonas gladioli) [12] [13] and other storage diseases on onion bulb. Several researches have been carried out regarding onion storage at various temperatures and it is found that refrigeration temperature lowers respiration rate and inhibits sprouting and decay, which retain the quality with increasing the shelf-life of onion [14].

Previous studies clearly show that inhibition of sprouting is prime concern to minimize the postharvest loss of onion during storage. Although several studies regarding shelf life of onion have been carried out, but there is no research work on storage behavior of Indian red onion (Pilli patti) at different conditions, which has motivated researchers to conduct a research with Indian red onion. From this research work, storage condition for longer shelf-life of Indian red onion can be suggested. Therefore, the main objective of this study is to know the storage behavior of Indian red onion with varying temperature under different storage conditions.

\section{Materials and Methods}

\subsection{Sampling}

"Indian red onion” was selected as sample of this research, provided by wholesaler. Usually, this variety of onion is cultivated with normal commercial practices in India. It is transplanted at the end of September while harvesting is done at the end of January. For this study, preparation of onion sample was carried out by sorting and cleaning to get uniform and good quality onions, which were subjected to different storage conditions.

\subsection{Storage of Red Onion}

\subsubsection{Refrigeration Condition}

The sample of red onion was manually packed in polyethylene pouches. Each polyethylene pouch was packed with 15 no. of red onion. Then each pouch was kept at four different refrigeration temperatures $\left(2.5^{\circ} \mathrm{C}, 6^{\circ} \mathrm{C}, 7^{\circ} \mathrm{C}\right.$ and $13^{\circ} \mathrm{C}$ ) for 60 days of storage period (Figure 1).

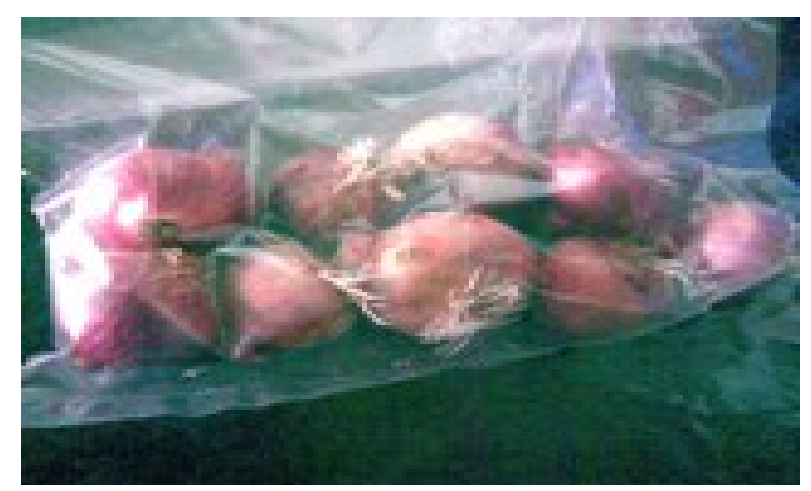

Figure 1. Red onion at refrigeration condition. 


\subsubsection{Ambient Conditions}

Red onion samples were stored under ambient conditions $\left(25^{\circ} \mathrm{C} \pm 3^{\circ} \mathrm{C}\right.$ and $\left.75 \% \mathrm{RH}\right)$ for 60 days by keeping open on wooden rack (Figure 2).

\subsection{Storage Behavior}

All measurements were carried out at each 10 days interval for monitoring and evaluating the storage behavior of red onion at different conditions.

\subsubsection{Weight Loss}

Weight loss of onion was measured and expressed as percent weight loss by taking the initial and final bulb weight after respective storage interval.

\subsubsection{Total Soluble Solids}

The total soluble solids (TSS) were measured by hand refractometer by placing 2 or 3 drops of clear juice of onion on the prism and expressed as degree brix $\left({ }^{\circ} \mathrm{Bx}\right)$.

\subsubsection{Number of Sprouted Onion}

The incidence of sprouting of onion was measured by manual counting and expressed as percentage. After each counting, the sprouted onions were discarded to avoid double counting. Bulbs that were sprouted and rotted at the same time were considered as sprouted.

\subsubsection{Number of Rotten Onion}

Rotten onion was measured by counting after physical observation of its texture, flavor and color around the neck and expressed as percentage. The rotted bulbs were also discarded after each counting to avoid double counting. The maximum shelf life of onion was considered as storage time having less significant change in selected parameters.

\subsection{Statistical Analysis}

All statistical analyses in this research were carried out using statistical package "SPSS" for Windows Version 20. Least significant difference between mean values was calculated using Duncan’s Multiple Range Test (DMRT) at $5 \%$ significance level.

\section{Results and Discussion}

\subsection{Weight Loss}

Figure 3 shows that storage conditions had significant $(\mathrm{p}<0.05)$ effect on weight loss of onion bulb. It was observed that weight loss of onion gradually increased with the increase of storage temperature throughout the storage period. Weight loss of onion was minimum at $2.5^{\circ} \mathrm{C}$, whereas highest weight loss was found for ambient

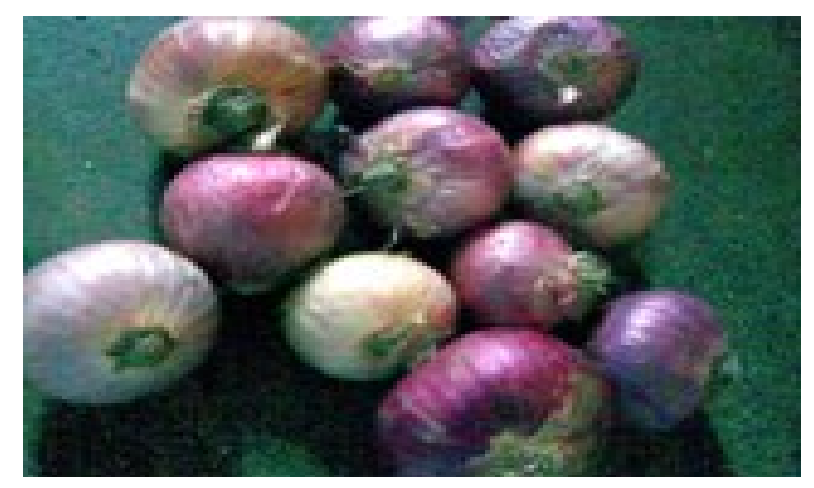

Figure 2. Red onion stored at ambient condition. 


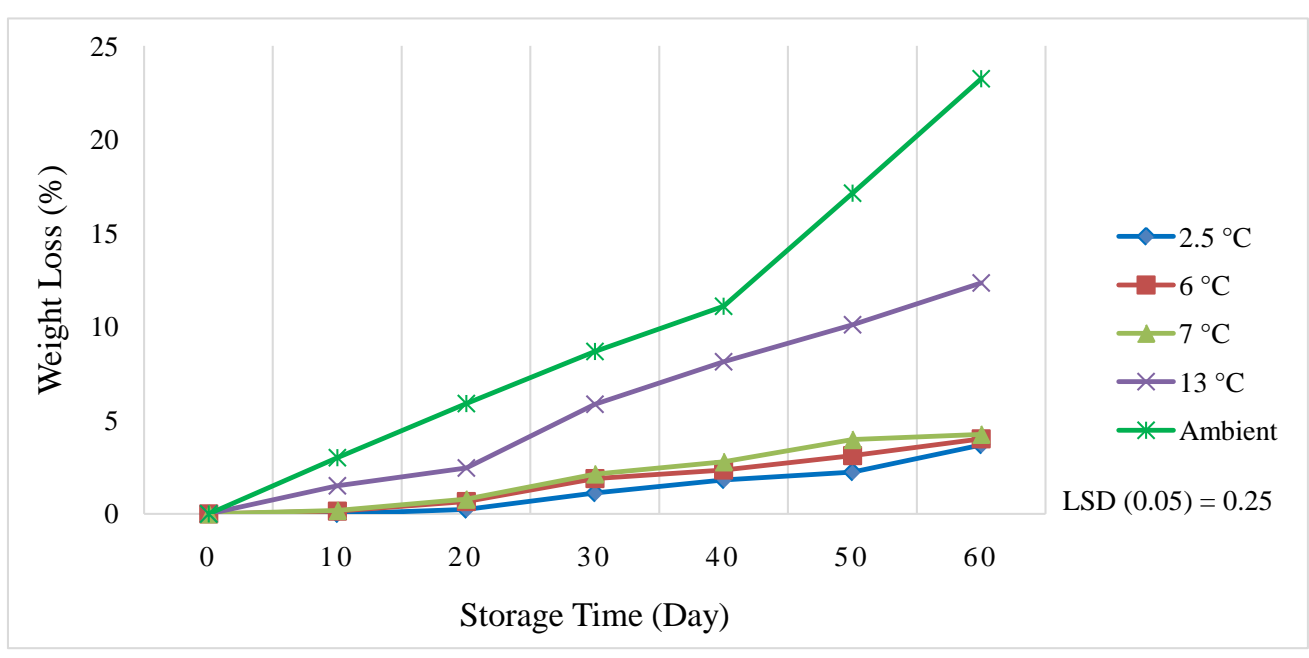

Figure 3. Weight loss during storage period.

conditions. After 40 days of storage, the rate of weight loss was higher at ambient condition. Higher moisture loss from the surface at ambient temperature caused maximum weight loss of onion. Hansen and Henriksen [15] reported that moisture loss from outer surface of onion causes slight increase in dry matter during storage. Finding on this study was also supported by Vintila et al. [16] who noted lowest weight loss of onion at cold condition than ambient condition.

\subsection{Total Soluble Solids}

It was revealed that total soluble solids (TSS) on onion gradually increased up to 40 days and then found to be decreased until termination of storage period for all treatments (Figure 4). However, significant $(p<0.05)$ difference in total soluble solids (TSS) was not found up to 20 days of storage. Ambient conditions exerted maximum increase in TSS while minimum was at $2.5^{\circ} \mathrm{C}$ at 40 days of storage time. At the end of 60 days, lowest and highest decreases in TSS were observed in onion stored at $2.5^{\circ} \mathrm{C}$ and ambient temperature respectively. This finding was in agreement with Woldetsadik and Workneh [17] who reported slight increase in TSS at the early stage of storage and then the reduction. According to Pak et al. [18], fructans are hydrolyzed to fructose during initial storage period and results in higher TSS. But dormancy period come to an end with the progress of storage while sprouting starts and sucrose is synthesized to organic acids and transported for the growth of sprout, ultimately it declines TSS content in bulbs.

\subsection{Sprouted Onion}

Storage temperature showed significant $(\mathrm{p}<0.05)$ effect on the sprouting of onion. Sprouting was observed to be increased among all samples with storage period. At the end of 60 days, lowest number of sprouted onion was noted at $2.5^{\circ} \mathrm{C}$, whereas highest number was found at $13^{\circ} \mathrm{C}$ and second highest number was recorded at ambient conditions (Figure 5). Vintila et al. [16] observed that sprouting was common to all varieties of onion stored at different temperatures where Daytona presented lowest degree of sprouting. Kukanoor [1] reported that sprouting caused shriveling of bulbs, consequently onion bulbs lost marketable quality.

\subsection{Rotten Onion}

Storage temperature significantly $(\mathrm{p}<0.05)$ affected the onion bulbs in respect of rotten onion. From Figure 6, it can be clearly noted that there was no rotten bulb in first 10 days of storage. After storage of 10 days, bulbs were found to be rotted and increased among all treatments with the progress of storage. Rotten bulb was observed maximum for onions stored at $13^{\circ} \mathrm{C}$, however lowest amount of rotten bulbs was recorded for ambient conditions at the end of 60 days. Wrapping of onion with polyethylene pouch for storing above refrigeration temperature might be possible reason of higher number of rotten onion at the end of storage time. Woldetsadik and Workneh [17] stated that rotting of bulbs may be attributed due to higher dose of nitrogen fertilizer, which 


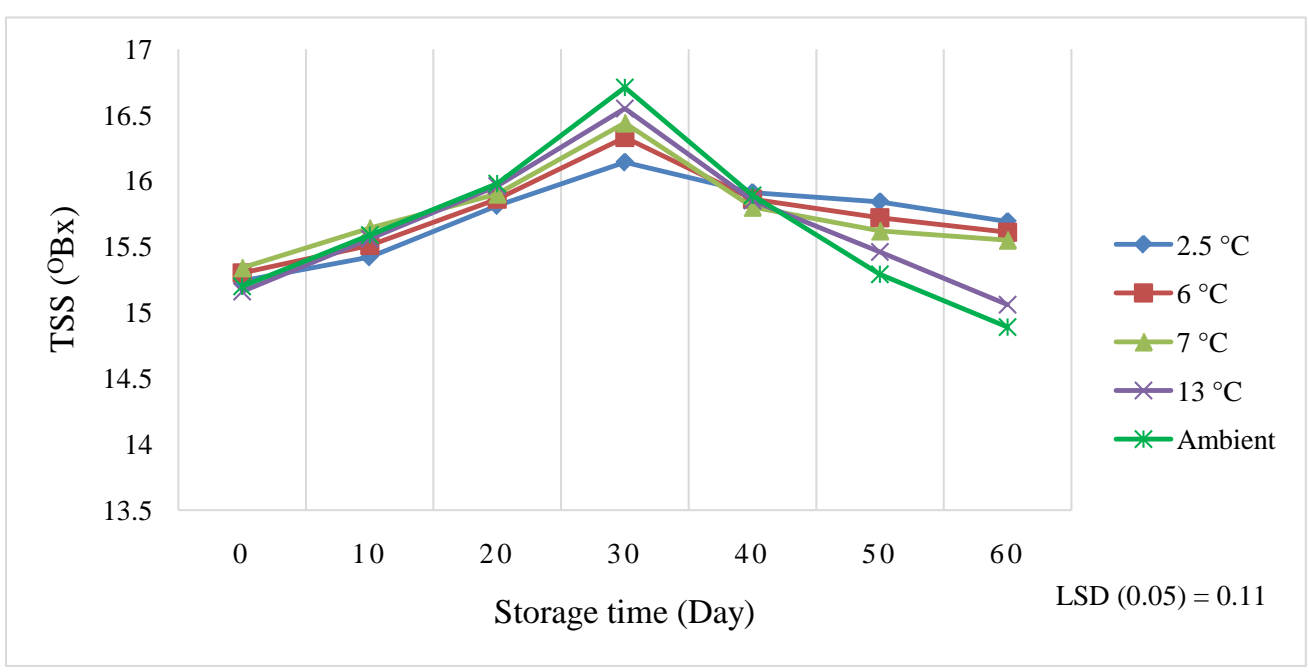

Figure 4. Change in TSS during storage period.

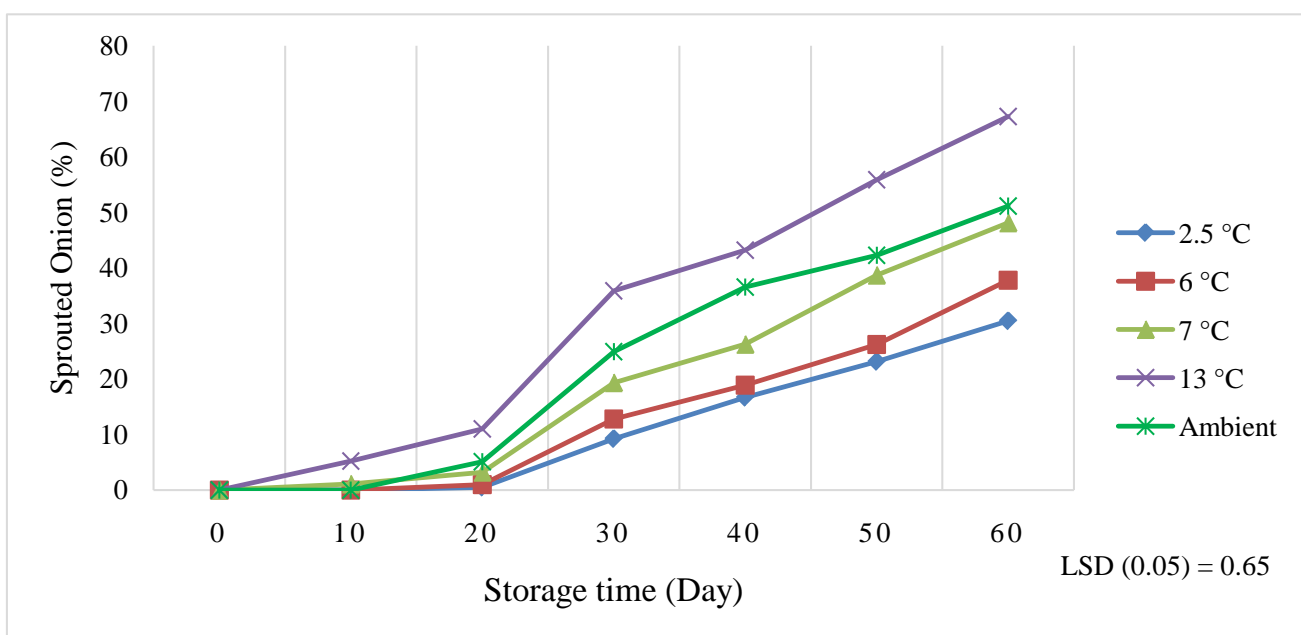

Figure 5. Sprouted onion during storage period.

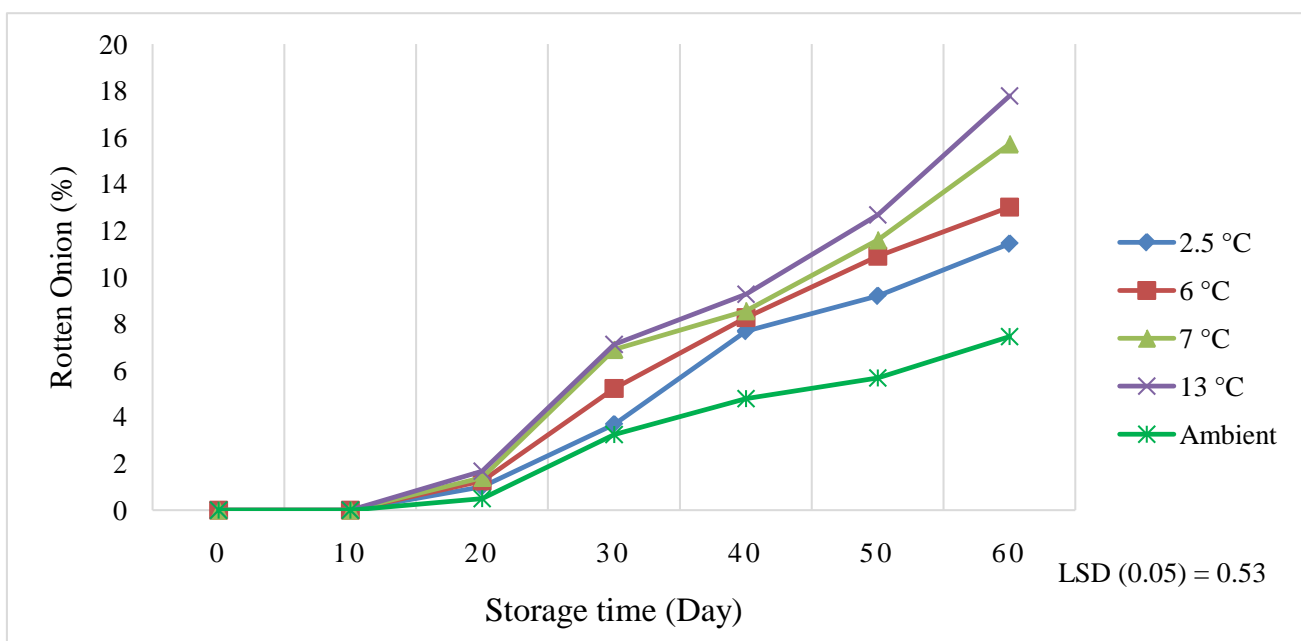

Figure 6. Rotten onion during storage period. 
produce bulbs with soft succulent tissues and thick neck, susceptible to decay by micro-organism and insects.

\section{Conclusion}

Different physiological changes occurred in red onion during storage period, which caused postharvest loss and reduced marketable quality. Results revealed that quality of stored onion was correlated with the storage temperature while maximum physiological change with higher weight loss was in ambient conditions $\left(25^{\circ} \mathrm{C} \pm 3^{\circ} \mathrm{C}\right.$ and $75 \% \mathrm{RH}$ ). Ultimately, ambient conditions shortened the storage life of red onion bulb. On the other hand, refrigeration temperature was found with less deleterious effects on storage life and postharvest quality of onion. Lastly, it was suggested that onion could be stored within polyethylene pouches at the range of refrigeration temperature of $2.5^{\circ} \mathrm{C}$ to $6^{\circ} \mathrm{C}$ for several months at industrial scale.

\section{References}

[1] Kukanoor, L. (2005) Post-Harvest Studies in Onion. Department of Horticulture, College of Agriculture, Dharwad University of Agricultural Sciences, Dharwad, 19-144.

[2] Randle, W.M. (2000) Increasing Nitrogen Concentration in Hydroponic Solutions Affects Onion Flavour and Bulb Quality. Journal of the American Society for Horticultural Science, 125, 254-259.

[3] Nayerabi, S.A.F. and Ahmed, A.H.M. (2001) The Commercial Vegetable of Pakistan. Tropical Science, 41, 95-99.

[4] Marwat, S.K., Rehman, F., Khan, M.A., Ahmad, M., Zafar, M. and Ghulam, S. (2011) Medicinal Folk Recipes Used as Traditional Phytotherapies in District Dera Ismail Khan. KPK. Pakistan. Pakistan Journal of Botany, 43, $1453-1462$.

[5] BBS (2009) Year Book of Agricultural Statistics of Bangladesh. Bangladesh Bureau of Statistics, Statistics Division, Ministry of Planning, Govt. of the Republic of Bangladesh.

[6] Adnan, K.M.M., Rahman, M.M. and Sarker, S.A. (2014) Marketing Channels and Post Harvest Practices of Onion: A Case of Bogra and Joypurhat District in Bangladesh. Universal Journal of Agricultural Research, 2, 61-66.

[7] Trevisan, J.N., Martins, G.A.K., Lopes, S.J. and Garcia, D.C. (1999) Yield and Post Harvest Storability of Lowland Grown Onion Genotypes. Ciência Rural, 29, 409-413. http://dx.doi.org/10.1590/S0103-84781999000300005

[8] Komochi, S. (1990) Bulb Dormancy and Storage. In: Rabinowitch, H.D. and Brewster, J.L., Eds., Onions and Allied Crops, I. Botany, Physiology and Genetics, CRC Press, Boca Ratan, 89-111.

[9] Gubb, I.R. and MacTavish, H.S. (2002) Allium Crop Science: Recent Advances, Onion Pre- and Postharvest Considerations. CABI Publishing, Wallingford, 233-265.

[10] Tanaka, K. (1991) Studies on the Black Mold Disease of Onion Bulbs Caused by Aspergillusniger van Tieghem (in Japanese, with English Summary). Bulletin of the Faculty of Agriculture Saga University Bull, 70, 1-54.

[11] Yoo, K.S., Andersen, C.R., Pike, L.M. and Sun Yoo, K. (1989) Determination of Postharvest Losses and Storage Life of “Texas Grano 1015Y” Onion. J. Rio Grande Valley Hort. Soc., 42, 45-50.

[12] Wall, M.M. and Corgan, J.N. (1994) Postharvest Losses from Delayed Harvest and during Common Storage of ShortDay Onions. HortScience, 29, 802-804.

[13] Wright, P.J. (1993) Effects of Nitrogen Fertilizer, Plant Maturity at Lifting and Water during Field-Curing on the Incidence of Bacterial Soft Rot of Onions in Store. New Zealand Journal of Crop and Horticultural Science, 21, 377-381. http://dx.doi.org/10.1080/01140671.1993.9513796

[14] Doug, W. (2004) Food and Rural Revitalization. Department University of Saskatchewan, Onions Production in Saskatchewan.

[15] Hansen, S.L. and Henriksen, K. (2001) Increasing the Dry Matter Production in Bulb Onions (Allium cepa L.). Denmark Department Fruit, Vegetable Food Sci., 2, 147-152.

[16] Vintila, M., Niculescu, F.A. and Romas, M. (2014) Technical Aspects Regarding the Preservation of Dry Onions in Different Storage Conditions. Bulletin UASVM Food Science and Technology, 71.

[17] Woldetsadik, S.K. and Workneh, T.S. (2010) Effects of Nitrogen Levels, Harvesting Time and Curing on Quality of Shallot Bulb. African Journal of Agricultural Research, 5, 3342-3353.

[18] Pak, C., Van der plas, L.H.W. and de Boer, A.D. (1995) Respiration and Ethylene Evolution of Certain Fruits and Vegetables in Response to Carbondioxide in Controlled Atmosphere Storage. Journal of Food Science and Technology, 30, 29-32. 